\title{
Implementasi Pemikiran RA. Kartini dalam Pendidikan Perempuan Pada Era Globalisasi
}

\author{
Alliyyah Zahra Permata Putri ${ }^{1}$, Hudaidah ${ }^{2}$ \\ ${ }^{1,2}$ Universitas Sriwijaya \\ alliyyahzahrapp@gmail.com \\ hudaidah@fkip.unsri.ac.id
}

\begin{abstract}
Abstrak
Artikel ini bertujuan menjelaskan informasi tentang pemikiran RA. Kartini dapat mengubah pendidikan perempuan dari masa penjajahan hingga masa kini. Menjelaskan arah pemikiran, dan berbagai ancaman serta hambatan dalam implementasiannya. Membahas pengaruh yang diberikan untuk kemajuan pendidikan wanita pada masa yang akan datang. Metode penelitian yang digunakan adalah metode studi pustaka. Data-data diperoleh dari internet, e-book, laporan penelitian terdahulu, jurnal, makalah, artikel, ensiklopedia, buku panduan atau penunjang dan sumber-sumber dari berbagai dokumen atau referensi tentang topik yang telah diajukan. Hasil penelitian menunjukkan bahwa pada era globalisasi sekarang ini, konsep pendidikan RA. Kartini masih relevan dan terbukti dapat dirasakan oleh perempuan pada zaman sekarang ini. Perempuan bisa bersekolah dan mencapai pendidikan setinggi-tingginya.
\end{abstract}

Kata Kunci: RA. Kartini, Pendidikan Perempuan, Globalisasi.

\begin{abstract}
Abstrac
This article aims to provide information about the educational thinking of RA. Kartini from the colonial period to the present. Explain the direction of thinking of RA. Kartini, and various threats and obstacles in the implementation of her thoughts. It discusses the impact given to the advancement of women's education in the future. The research method used is the literature study method. Data were obtained from the Internet, e-books, previous research reports, journals, papers, articles, encyclopedias, guide or supporting books and sources from various documents or references on topics that have been proposed. The results showed that in the current era of globalization, the concept of education RA. Kartini is still relevant and proven to be felt by women today. Women can go to school and achieve the highest education.
\end{abstract}

Keywords: RA. Kartini, Women's Education, Globalization.

\section{Pendahuluan}

Pembicaraan tentang perempuan adalah hal menarik untuk diperbincangkan dan pembahasan yang seakan tidak ada akhirnya. Perempuan yang sering direndahkan karena banyak dari mereka yang tidak bisa untuk menduduki high profile, namun sekarang kenyataannya isu-isu yang beredar seperti kekuasaan, kedudukan kesetaraan, peranan, aktivitas, keberanian dan kemadirian di khalayak ramai banyak sekali yang menyangkut- 
Jurnal Humanitas

Vol. 7 No. 2, Juni 2021, hal. 69-80

pautkan dengan perempuan sebagai topik utama mereka. Hal tersebut menimbulkan kontroversi dan menyebabkan banyak orang bertindak emosional. Sebelum sampai pada perkembangan abad ke-20 kesejajaran kaum perempuan secara mutlak tidak akan pernah sama dengan kaum laki-laki, baik dalam hal apapun seperti bakat, kemampuan dan juga terkhusus hal-hal yang berkaitan dengan bidang pendidikan (Indonesia, 2000).

Perempuan pada masa itu tidak diperbolehkan untuk mendapatkan hak untuk menempuh jenjang pendidikan bahkan perempuan juga tidak boleh melakukan interaksi atau bersikap interaktif terhadap lingkungan sosial baik dengan dirinya sendiri ataupun dengan masyarakat secara terang-terangan. Perempuan yang hanya ditugaskan untuk berada di rumah mereka, menjaga dan merawat apa yang ada di dalamnya dan melaksanakan semua hal sebagai anak, istri, dan sebagai menantu yang baik, tanpa adanya kebebasan untuk memiliki pemikiran terbuka apalagi dalam bertingkah laku yang seharusnya diberikan hak kepada seluruh manusia seutuhnya (Nata, 1997).

Melihat permasalahan tersebut, beberapa tokoh terutama tokoh-tokoh perempuan yaitu: Raden Ajeng (RA) Kartini, Dewi Sartika, Rahmah El-Yunusiyah, Cut Nyak Dien, dan tokoh lainnya, tergugah untuk mengubah dan merencanakan perkembangan cara berpikir masyarakat tentang perempuan dengan mengubah kesejajaran kedudukan perempuan dengan laki-laki, terkhususnya dalam bidang pendidikan.

Salah satu diantara tokoh tersebut adalah Raden Ajeng (RA) Kartini. RA. Kartini yang setelahnya lebih dikenal dengan Kartini adalah tokoh perempuan yang sangat berpengaruh dalam sistem pendidikan di Indonesia terutama bagi kaum wanita. Beliau adalah tokoh yang berani, cerdas dan bijaksana yang selalu berjuang untuk pencapaian pendidikan Indonesia yang lebih baik. Berkat semangat emansipasi dan keberhasilan yang Ia peroleh inilah yang membuatnya dikukuhkan sebagai salah satu pahlawan diantara tokoh-tokoh lainnya yang berjasa bagi Negara Kesatuan Republik Indonesia (NKRI).

RA. Kartini yang secara resmi telah dikukuhkan sebagai salah satu Pahlawan Nasional Indonesia dimana tertera Surat Keputusan Presiden RI Nomor 108 pada tanggal 02 Mei 1964 (Indonesia, 1964). Raden Adjeng Kartini yang lahir di Jepara, Hindia Belanda, 21 April 1879. Sehingga pada tanggal 21 April tepat pada tanggal kelahiran Kartini, Indonesia setiap tahunnya memperingati tanggak tersebut sebagai hari Kartini atau sebenarnya lebih tepat disebut Raden Ayu Kartini.

Sosok RA. Kartini tidak pernah lepas dari topik emansipasi wanita, karena uasaha dengan dedikasi yang ia lalui untuk masa depan wanita Indonesia pada zaman mendatang. Namun pada era globalisasi seperti sekarang ini, kata emansipasi yang telah dibangun oleh 
Jurnal Humanitas

Vol. 7 No. 2, Juni 2021, hal. 69-80

beliau telah mengalami pergeseran arti. Banyak sekali para perempuan yang belum dapat mengaktualisasikan dan mengimplementasikan hal tersebut kepada realita kehidupan. Jika dahulu perjuangan yang harus dilalui seorang Kartini adalah harus melawan ketidakadilan terhadap wanita, namun sekarang kenyataannya menjaga keadilan dan makna emansipasi dapat dilakukan dengan cara yang terbilang cukup mudah dilaksanakan.

Cara yang dapat dilakukan agar pengimplementasian dari pendidikan RA. Kartini adalah dengan berupaya untuk tidak menggantungkan hidup kepada orang lain, percaya kepada kemampuan diri sendiri, menjadi perempuan yang kuat menghadapi berbagai ancaman dan hambatan pada zaman modernisasi, belajar untuk berani dan bertanggung jawab atas keputusan yang telah diambil. Karena semestinya perempuan dapat berdiri dengan bahu yang kuat, tubuh yang kokoh dan hati yang tidak kenal kata hancur, dapat mengendalikan emosi dan tidak tersulut perkataan yang belum terbukti kepastiannya. Sebagai perempuan yang modern sudah seharusnya bersikap bijaksana dan cerdas dalam menghadapi berbagai persoalan hidup. Tidak perlu berjuang melawan penjajah dan para pejabat Belanda untuk mendapatkan pendidikan dan mempertahankan semangat emansipasi, cukup dengan melakukan hal-hal baik menghargai apa yang telah dimiliki dan bersyukur atas kehendak yang Tuhan beri, walaupun hal tersebut sederhana namun hal tersebut dapat memberikan pernyataan bahwa perempuan era globalisasi juga masih tetap mempertahankan pemikiran Kartini, dan mewujudkan semangat emamsipasi yang telah Ia perjuangakan, dimana hal tersebut dapat menghasilkan berbagai manfaat dan motivasi bagi diri sendiri ataupun bagi banyak orang dilingkungan sekitar.

Beberapa penelitian tentang RA. Kartini telah dilakukan, diantaranya penelitian Amar (2017) tentang "Perjuangan Gender dalam Kajian Sejarah Wanita Indonesia Pada Abad XIX". Kemudian penelitia Muthoifin \& Wachidah (2017) tentang "Pemikiran Raden Ajeng Kartini Tentang Pendidikan Perempuan dan Relevansinya Terhadap Pendidikan Islam”. Ada juga penelitian Fatonah (2015) tentang "Relevansi Pemikiran R.A. Kartini Tentang Pendidikan Wanita Indonesia Dalam Kemajuan Bangsa (1891-1904)”. Kemudian ada penelitian Sudrajat (2007) tentang "Kartini: Perjuangan dan Pemikirannya". Penelitian Mulyani (2017) tentang "Kesetaraan Gender Dalam Tulisan RA. Kartini Perspektif Pendidikan Islam". Penelitian tersebut sangat relevan sebagai rujukan dalam menulis penelitian ini, sekaligus menjelaskan keberbedaan dengan penelitian sebelumnya. Keberbedaan penelitian sebelumnya dengan penelitian ini terletak pada aspek relevansi pemikiran RA. Kartini di era globalisasi. Hal ini di penelitian-penelitian sebelumnya tidak 
Jurnal Humanitas

Vol. 7 No. 2, Juni 2021, hal. 69-80

banyak dibahas. Oleh karena itu urgensi penelitian ini menjelaskan tentang pemikiran RA. Kartini yang masih relevan dalam kehidupan global.

Berdasarkan latar belakang tersebut artikel ini bertujuan untuk mengimplementasikan sikap emansipasi dari pemikiran pendidikan RA. Kartini dan memusatkan fokus kepada wanita era globalisasi, agar tetap mewujudkan semangat emansipasi. Sebagaimana kita lihat pada masa modernisasi ini banyak sekali perempuan yang tidak bersyukur atas hak kebebasan yang telah ada. Disamping kebebasan yang diberi banyak sekali urgensi yang terjadi dikalangan perempuan Indonesia yang turut membantu dan memrikan konstribusi bagi pemikiran pendidikan dengan landasan semangat Kartini. Perempuan masa kini yang hanya memikirkan popularitas, kecantikan, dan material dunia lainnya daripada menuntut ilmu untuk mencapai cita-cita yang mulia. Penulisan artikel ini diharapkan agar dapat menjadi acuan dan menimbulkan manfaat dari segi semangat RA. Kartini muda Indonesia. Agar semangat emansipasi yang telah terkikis dapat menguat dan teguh kembali.

\section{Metode Penelitian}

Metode yang digunakan dalam penulisan artikel ilmiah adalah metode pustaka atau literatur (Zed, 2008). Dalam merancang artikel ini penulis memfokuskan kepada bagaimana cara pengimplementasian pemikiran dari RA. Kartini di masa kini. Dengan meminimalisir ancaman dan hambatan, memerikan solusi yang tepat dengan zaman tanpa mengubah pondasi awal dari semangat emansipasi, serta mencapai keberhasilan untuk setiap wanita. Metode metode penelitian ini menggunakan sistematika membaca, memeriksa, dan menggunakan informasi bahan bacaan seperti internet, e-book, laporan penelitian terdahulu, jurnal, makalah, artikel, ensiklopedia, buku panduan atau penunjang dan sumber-sumber lainnya. Kemudian menuangkan semua metode tersebut ke bagian abstrak, pendahuluan, hasil dan pembahasan, hingga pada kesimpulan.

\section{Pembahasan}

Pendidikan adalah elemen penting di dalam suatu kehidupan. Pendidikan dapat ditempuh semua usia, semua orang tanpa terkecuali baik laki-laki maupun perempuan. Pendidikan laki-laki dan perempuan di Indonesia yang awalnya tidak disetarakan dimana hanya bersifat berat sebelah, kini pendidikan perempuan berhasil menyetarakan hakikatnya sama dengan laki-laki. Pendidikan dan perempuan memanglah kedua elemen yang berbeda namun hal tersebut tidak dapat dipisahkan. Sistem pendidikan yang bersifat keadilan humanis pasti akan menyertakan perempuan di dalam sistem pendidikan tersebut, karena apabila 
Jurnal Humanitas

Vol. 7 No. 2, Juni 2021, hal. 69-80

menyepelekan hakikat perempun di dalam suatu aliansi pendidikan maka sama saja dengan menghalalkan dominasi kekuasaan dan keberhaslan bagi segenap manusia (Muthoifin \& wachidah, 2017).

Salah satu permasalahan yang bisa dianggap paling berat dan menjadi tantangan masa kini bagi penddikan perempuan adalah rekognisi pendidikan bagi perempuan, hal ini sangat banyak dijumpai pada realita kehidupan karena perempuan dipandang sebelah mata. Pendidikan perempuan yang awalnya tidak diterapkan secara fundamental namun hanya dilaksanakan sebagai formalitas saja, bahkan bayak sekali oknum yang tidak memberikan kesempatan secara bebas untuk kaum perempuan menjalankan pendidikan dengan keadilan dan fasilitas yang seharusnya mereka gunakan. Hal tersebut di lakukan agar para perempuan tetap tunduk kepada pemerintahan yang mayoritas di dalamnya adalah kaum laki-laki. Banyak sekali argumentasi agar sama sekali tidak memberikan perempuan kesempatan untuk menjalankan pendidikannya (Hartutik, 2015).

Pemikiran akan pentingnya pendidikan untuk perempuan tidak hanya datang dari pemikiran yang dibayangkan oleh tokoh-tokoh luar negri saja, namun dalam Republik Indonesia terdapat penggiat dan pengukuh hak perempuan pribumi. Salah satu diantara banyaknya tokoh perempuan yang berperan adalah RA. Kartini. Kartini adalah perempuan muda yang berjuang melawan dan mempertegas hak perempuan sebagaimana mestinya. Diimplementasikan dalam semangat emansipasi dan Kartini menuangkan pemikirannya kedalam surat yang dikirimkan kepada J. H. Abenadon. Kumpulan surat pribadi Kartini yang selanjutnya diterbitkan tepat pada tahun 1912 dengan judul Habis Gelap Terbitlah Terang (Door Duisternis Tot Licht). Kumpulan surat Kartini tersebut kini telah menjadi sebuah alternatif pemikiran tentang pendidikan bagi perempuan. sebagai kritik dan isu yang ada pada realitas, bahwasannya perempuan juga sangat perlu pendidikan bagi kelangsungan hidup di masa depan. Salah satu pokok dari pemikiraan kartini adalah semangat emansipasinya. Emansipasi adalah upaya untuk mewujudkan kesetaraan perempuan dalam berbagai bidang khususnya dalam mendapatkan pendidikan (Khamdiyah, 2016).

Pemikiran dari Kartini dipengaruhi langsung oleh lingkungan sosial pada saat itu dimana hal tersebutlah yang menimbulkan suatu aspek pemikiran yang sangat penting yaitu pendidikan seagai alat untuk memajukan sebuah bangsa. Ilmu pengetahuan yang didapat oleh seseorang merupakan salah satu jalan mencapai kebahagiaan baik bagi individu ataupun kelompok masyarakat. Kartini memiliki harapan yang sangat dalam bagi kaum bumiputra apalagi bagi kaum perempuan untuk mendapatkan pendidikan. Semua hal ini bertujuan untuk 
Jurnal Humanitas

Vol. 7 No. 2, Juni 2021, hal. 69-80

mencetak individu yang mempunyai kecerdasan akal dan budi pekerti yang luhur (Sutrisno, 1979).

Harapan dan keinginan Kartini disertai aspek dan fasilitas dari pembelajaran yang ia dapat semasa bersekolah itulah yang membuat pemikirannya semakin terbuka bahwa pendidikan adalah komponen yang sangat penting bagi bangsanya, terutama kaum perempuan. kartini mengharapkan manusia bumi putra menjadi individu yang memiliki kecerdasan akal dan keluhuran budi pekerti dalam proses pendidikan. Tertulis di dalam pasal 31 ayat 3 UUD Negara RI tahun 1945 "Pemerintah mengusahakan dan menyelenggarakan satu sistem pendidikan nasional yang meningkatkan keimanan dan ketakwaan serta akhlak mulia dalam rangka mencerdaskan kehidupan bangsa yang diatur dengan undang-undang”.

Hal ini membuktikan bahwa pemikiran kartini sudah jauh melampaui zamannya. Saat dirinya berusia 12 tahun, Kartini muda sudah mampu membuat gagasan pendidikan secara filosofis maupun sosiologis. Ketika kaumnya, kaum perempuan yang pada saat itu sedang terikat dengan adat yang kolot sehingga bangsanya terbelenggu oleh rantai kebodohan. Namun beliau teetap teguh dengan pemikiran dan harapannya, ia menuangkan kegelisahannya dalam lembar surat kepada seorang sahabatnya di Belanda. Kartini mengungkapka bahwa ia seakan-akan mencoba mengubah alam kegelapan yang mengitari bangsanya, dan mengikis habis dan rata melalui dunia pendidikan. Melalui pendidikan bangsa akan menuju ke zaman terang benderang ujar beliau. Bahasa yang kemudian di sederhanakan oleh Abendanon sebagai Habis Gelap Terbitla Terang.

Peran Kartini dlam memajukan pendidikan di Indonesia adalah salah satu bukti kontribusi wanita dan bukti kepedulian dirinya terhadap bangsa Indonesia, kejdian tersebut pun dicetak dengan tinta emas di dalam sejarah Indonesia. Karena kondisi para kaum perempuan yang pada masa itu sangat memprihatinkan, beliau mendorak kondisi tersebut dengan berbagai cara. Salah satu diantara usaha Kartini adalah mendirikan sekolah khusus wanita dan membangun perpustakaan bagi anak-anak perempuan.

Kartini yang beragamakan Islam, seakan telah menjawab seruan Alquran dalam surah Al-Baqarah ayat 257. Buku tersebut seperti menjelaskan usaha seorang Kartini untuk menerjemahkan wahyu ilahiah terhadap pemaknaan kegelapan. Kartini seperti memberikan cahaya terang sebagai manifestasi bentuk keimanannya kepada Allah SWT yang dimana disebutkan bahwa Kartini mencoba mengubah kondisi kekufuran menuju cahaya hidayah bagi pendidikan masa depan. Kartini juga meyakini hal yang pernah diungkapkan oleh ayahnya, bahwa pendidikan (ilmu pengetahuan) akan membawanya menuju kebahagiaan hidup dan kesejahteraan. Pradigma berpikir ini selaras dengan Alquran pada surah Al- 
Mujadalah ayat 11 "Allah akan meninggikan orang-orang yang beriman dan berilmu pengetahuan beberapa derajat".

Konstruksi dari cara berpikir kartini mirip dengan gagasan pendidikan, intelektual sekaligus penyair muslim, Muhammad Iqbal (1877-1938). Iqbal membuat rumusan yang memadukan pendidikan berbasis al-fikr dan zikir yang termuat dalam bukunya The Reconstruction of Religous Tought in Islam (1971). Pemikiran seperti ini memadukan aspek kognitif dan afektif atau Kartini menyebutkannya sebagai kecerdasan akal, budi dan juga jiwa. Pemikiran kartini yang telah melewati batas geografis dan gender sehingga ia layak jika didaulat sebagai salah satu tokoh pelopor pendidikan bangsa Indonesia. Kontekstualisasi gagasan pendidikkan oleh Kartini dalam menjawab realitas dunia dapat menjadi salah satu autokritik dan suatu refleksi.

Surat-surat Kartini tak hanya diterjemahkan oleh Abendanon melainkan diterjemahkan juga oleh Sulastin Sutrisno. Mulanya saat Sulastin melanjutkan studi di bidang sastra tahun 1972 ia mulai menerjemahkan Door Duisternis Tot Licht di Universitas Leiden, Belanda. Hal tersebut ia lakukan karena salah seorang dosen pembimbing di Leiden meminta Sulastin untuk menerjemahkan buku kumpulan dari surat-surat Kartini tersebut. Tujuan sang dosen saat itu adalah agar Sulastin dapat menguasai bahasa Belanda dengan sempurna. Pada tahun 1979 sebuah buku berisi terjemahan dari seorang Sulastin Sutrisno pun terbit dengan judul Surat-surat Kartini, Renungan Tentang dan Untuk Bangsanya. Sulastin menyatakan bahwa judul yang seharusnya menurut bahasa Belanda adalah : "Surat-surat Kartini, Renungan Tentang dan Untuk Bangsa Jawa”. Namun hal tersebut membuat Sulastin menilai bahwa, meski tertulis Jawa tetappi hal yang didambakan sesungguhnya oleh Kartini adalah kemajuan untuk seluruh bangsa yaitu Indonesia. Terjemahan dari Suastin Sutrisno ini juga dipakai dalam buku Kartini yaitu, Surat-surat kepada Ny RM Abendanon-Mandri dan Suaminya (Suparno, 2001).

Buku lainnya yang berisi terjemahan dari surat-surat Kartini ialah Letters from Kartini, An Indonesian Feminist 1900-1904 yang diterjemahkan oleh Joost Coté. Ia tidak hanya menerjemahkan surat-surat yang ada versi Abendanon, namun ia juga menerjemahkan seluruh surat asli Kartini pada Ny Abendanon-Mandri hasil temuan terakhir. Pada buku terjemahan Joost Coté dapat ditemukan surat-surat yang tergolong sensitif dan tidak ada dalam buku sebelumnya versi Abendanon. Menurut Joost Coté, seluruh perjuangan pergulatan Kartini dan penghalangan pada dirinya sudah saatnya untuk diungkap. Buku terjemahan Joost Cotéini telah memuat 108 surat-surat Kartini kepada Ny Rosa Manuela 
Jurnal Humanitas

Vol. 7 No. 2, Juni 2021, hal. 69-80

Abendanon-Mandri dan suaminya JH Abendanon termasuk 46 surat yang dibuat oleh Rukmini, Kardinah, Kartinah, dan Soematrie (Sudrajat, 2003).

Selanjutnya, sebuah buku yang berisi kumpulan surat yang diberikan kepada stella zeehandelar pada periode 1899-1903 diterbitkan untuk memperingati 100 tahun wafatnya seorang Kartini. Isinya memperlihatkan wajah dan sifat lain dibalik seorang Kartini. Koleksi surat Kartini itu diterjemahkan dengan judul Aku Mau “... Feminisme dan Nasionalisme yang dikumpulkan oleh Dr. Joost Coté dan surat-surat Kartini ini dikirimkan kepada Stella Zeehandelaar pada tahun 1899-1903. Moto kartini yang akhirnya terkenal “Aku Mau ...”, sepenggal ungkapan yang selama ini tidak pernah terungkap, terlihat, atau bahkan menjadi bahan perbincangan di mata khalayak ramai. Kartini yang membicarakan banyak hal pada surat ini : sosial, budaya, agama, bahkan juga korupsi (Sastroatmojo, Suryanto, op. cit., hlm. $60)$.

Namun masih banyak kali orang yang meragukan kebenaran dari surat-surat yng ditulis oleh Kartini. Ada dugaan yang mengatakan bahwa J.H. Abendanon yang merupakan seorang Menteri Kebudayaan, Agama, dan Kerajinan pada saat itu telah dicurigai merekaysa surat-surat Kartini. Kecurigaan ini muncul karen pda saat itu buku dan kumpulan surat Kartini lainnya terbit saat pemerintahan kolonial Belanda sedang menjalankan sistem politik etis di area Hindia Belanda, dan Abendanon ini adalah salah seorang tokoh penting yang turut mendukung sistem politik etis tersebut. Sampai pada sat ini pun sebagian besar dari naskah asli surat Kartini belum bahkan tak kunjung diketahui kebenaran dari keberadaannya. Tetapi menurut almarhumah Sulastin Sutrisno, jejak keturunan dari tokok Abendanon pun turut sukar untuk di lacak oleh Pemerintah Belanda.

Namun hal ini tidak membuat masyarakat kemudian mengasingkan perjuangan Kartini. Kedudukan perempuan yang telah berubah berkat Kartini pun tak luput dari alasan mengapa beliau bisa dikenal sampai sejauh ini. Kedudukan perempuan pada masa penjajahan sebelum adanya emansipasi wanita oleh Kartini yang dirasakan sangat memprihatinkan, dimana seorang perempuan tidak bisa bebas keluar rumah apalagi untuk duduk dibanhku sekolah dan bersekolah seperti normalnya kita pada saat ini. Adanya perbedaan besar antara kaum perempuan dan laki-laki dengan ketidakailan antar gender yang membuat dampak yang sensitif kepada anak perempuan, sampai pada masa mereka tidak dianggap penting dan hanya dipertuntutkan untuk menjadi seorang istri dan ibu rumah tangga saja. Ketika usia 10 atau 12 tahun pada masa sebelum masa Kartini perempuan sudah bebas dari keluarganya yang bermakna bahwa mereka sudah dinikahkan pada umur sedini itu. Namun hal tersebut berubah saat datangnya masa Kartini, kaum perempuan sudah bisa dan bebas bersekolah, adanya 
Jurnal Humanitas

Vol. 7 No. 2, Juni 2021, hal. 69-80

kesetaraan antara kaum perempuan dan laki-laki, dan perempuan yang tidak selalu dituntut menikah dan membatasi umur dini mereka untuk melanjutkan jenjang pernikahan (Amar, 2017).

Kartini dapat dikatakan juga sebagai tokoh penunjang dan pembaru dibidang pendidikan perempuan, yang memiliki banyak terobosan dalam mengajarkan dan mempublikasikan pentingnya arti pendidikan bagi perempuan. Hingga pada masa kepresidenan Soekarno, beliau menafsirkan perempuan kedalam sepenggal kalimat singkat "Perempuan itu tiang negeri" ujarnya, maka seharusnya perempuan sadar akan posisi dan keduukannya untuk mencetak peradaban bangsa agar mengalami kemajuan. Alat untuk mewujudkan jalan perempuan adalah pendidikan, jika perempuan mendapatkan pendidikan yang baik, maka tidak heran jika suatu negara atau institusi yang dimana perempuan tersebut berpijak akan terangkat martabat dan derajat bangsa tersebut (Sasroatmojo, 2005).

Pendidikan bukan hanya berkaitan dengan hal mengasah akal dan tingkat intelektual saja, namun juga memperhatikan hal-hal lain seperti kepribadian. Kartini menyatakan jika pendidikan bukan hanya tentang mempertajam akal saja, tetapi budi pekerti pun juga perlu dan harus dipertinggi. Maka intinya adalah alam menjalankan sistem pendidikan, perempuan tidak hanya mengutamakan tingkat kecerdasarn semata, namun juga menanamkan budi pekertinya pula. Jika hanya mengunggulkan sisi kecerdasan tanpa memperhatikan sisi lainnya maka yang terjadi adalah rasa superioritas dan rendahnya sikap kemanusiaan.

Pendidikan diberikan bukan hanya dalam tingkat sekolah atau lembaga formal saja, namun diperlukan juga bimbingan pendidikan non formal. Pendidikan formal tidak sepenuhnya berjalan baik jika tidak diiringi oleh pendidikan non formal. Pendidikan non formal sendiri yang berupa peranan keluarga, lingkungan, serta masyrakat sekitar dalam penerapan pendidikan. Josoef sulaiman mengemukakan dalam Konsep Dasar Pendidikan Luar Sekolah mengemukakan:

"Di dalam keluargalah anak kali pertama menerima pendidikan, a pendidikan yang diperoleh dalam lingkungan keluarga ini merupakan pendidikan yang paling penteng, terpenting atau utama terhadap perkembangan kepribadian anak."

Dalam pembentukan dan pengembangan karakter seorang anak, komponen terpenting yang mendukung tersebut adalah keluarga. Itulah mengapa penekanan pendidikan kerap kali lebih banyak diberikan pada masa pendidikan non formal seperti pendidikan keluarga misalnya, karena keluarga adalah salah satu pendidik terdekat dengan seorang anak. Hal ini juga berkaitan pula dengan penjelasan tentang peran perempuan untuk memberikan 
Jurnal Humanitas

Vol. 7 No. 2, Juni 2021, hal. 69-80

pendidikan atau menjadi ibu dan mendidik anaknya untuk menjadi generasi penerus bangsa selanjutnya.

Kesadaran perempuan terhadap pentingnya pendidikan masih tergolong sangat rendah pada masa itu, tak jarang hal tersebut terjadi karea faktor dari perempuan itu sendiri. Terkadangperempuan masih merasa nyaman hingga terjebak pada zona nyaman yang tak jauh dari dunia gemerlap, karena faktor intermal maupun eksternal yang menyebabkan hal tersebut dan membuat perempuan rabun akan dunia pendidikan. Dalam hal pendidikan perlu ditekakan jikalau terjdi kurang meratanya pendidikan terutama untuk perempuan, tidk hanya diakibatkan oleh faktor ekonomi namun juga ada pengaruh dari budaya. Dahulu Kartini memberikan akses pendidikan secara meluas, namun dalam praktiknya zaman globalisasi saat ini masih belum berjalan dengan maksimal, shingga perempuan diiaratkan seperti masih terkungkung dalam sebuah sangkar emas (Fillah, 2008).

Hal tersebut tidak menghambat seluruh perempuan Indonesia untuk meneruskan semangat emansipasi, karena faktanya sebagian perempuan nusantara telah berkarya sesuai dengan bakat yang mereka miliki. Tak hanya itu untuk mengeksplor pengetahuan, berbagi kasih tentang pendidikan, memberikan gambaran bahwa perempuan tidak lemah seperti yang selama ini duni kira. Banyak sekali perepuan-perempuan Indonesia yang berprestasi mewujudkan mimpi negri dan membanggakan nama NKRI. Seperti contoh mantan Menteri Kelautan dan Perikanan yang masih hangat diperbincangkan, Ibu Susi Pudjiastuti. Saat beliau menjabat sebagai Menteri Kelautan dan Perikana beliau dikenal dengan kebijakan yang tegas dalam kementriannya. Beliau sangat enindaklanjuti kasus penangkapan ikan haram, bahkan nama Ibu Susi ini sering dikaitkan dengan tindakannya yang menghukum para oenangkap haram ini dengan menenggelamkan kapal-kapal nelayan asing yang didapati sangat bergian mengeksplor sumber daya alam yang ada di perairan Indonesia upaya beliau membuahkan hasil, seperti yang ditunjukkan salah satu penelitian yang diterbitkan oleh Jurnal Nature menunjukkan bahwa "polisi agresif" Ibu Susi terhadap penangkapan ikan haram telah mengurangi $25 \%$ daya tangkan dan berpotensi menabah keuntungan sebsesar $12 \%$ dan menambah jumlah tangkap hingga 14\% (Bangun, 2021). Hal tersebut adalah salah satu contoh dimana pengimplementasian emansipasi wanita pada zaman globalisasi seperti sekarang ini, Ibu Susi Pudjiastuti yang dianggap menyelamatkan laut Indonesia dikenal seperti Kartini era globalisasi. Hal tersebut tidak menutupkemungkinan untuk para perempuan penerus bangsa lainnya, tidak hanya dengan cara berperang melawan penjajah dengan cara melawan diri sendiri dari rasa malas untuk belajarpun sudah membuktikan bahwa kita menghargai perjuangan Kartini pada zamannya hingga sekarang ini. 


\section{Kesimpulan}

Pendidikan adalah komponen yang bisa mengangkat derajat dan martabat suatu bangsa. Pendidikan yang dimaksudkan oleh seorang Kartini merupakan pendidikan yang dapat diterima semua kalangan, tidak hanya laki-laki saja namun mencakup pula kalangan perempuan Indonesia. RA. Kartini yang selau memperjuangkan kaumnya, agar perempuan diberikan kebebasan sehingga bisa bersekolah, menuntut ilmu, hingga melakukan peran sosial dan tidak duduk diam di dalam rumah. Beliau bahkan bercita-cita membangun sekolah atau pendidikan yang mengutamakan budi pekerti dan menggunakan pendidikan agama. Perjuangan yang tidak mudah untuk menghadapi sekelompok masyarakat yang pada masa itu masih mempunyai pola pikir kuno, dimana derajat perempuan dan laki-laki itu jauh berbeda. Tetapi hal tersebut tidak menggagalkan perjuangan Kartini, sekalipun memerlukan waktu yang lama dan panjang serta menghadapi berbagai ancaman, hambatan tantangan bahkan gangguan yang datang dari lingkungan disekitarnya. Terukti dari apa yang dapat dirasakan perempuan pada zaman globalisasi seperti dewasa ini, perempuan bisa bersekolah dan mencapai pendidikan setinggi-tingginya. Sudah tidak ada lagi perbedaan hak antar perempuan dan laki-laki, sehingga perempuan sedemikian bebas haknya. Perempuan yang diperbolehkan untuk menjadi cerdas dan mengimplementasikan emansipasi pada era modern ini dengan bakat dan pengetahuan dari yang mereka dapat selama pendidikan dan sosialisi. Perempuan yang tidak lagi memiliki batasan untuk mencapai cita-cita seperti menjadi pengajar, dokter, polisi hingga untuk menjadi salah satu pejabat pemerintahan. Kartini benarbenar telah memberikan masa depan yang cerah untuk perempuan. Hingga saat ini banyak sekali perempuan Indonesia yang berprestasi dan mempunyai tekad emansipasi melanjutkan perjuangan Kartini untuk mencerdaskan dan menyamaratakan kedudukan kaum laki-laki maupun perempuan.

\section{Daftar Rujukan}

Abudin, Nata. 1997. Filsafat Pendidikan Islam. Jakarta : Wacana Ilmu.

Amar, S. (2017). Perjuangan Gender dalam Kajian Sejarah Wanita Indonesia Pada Abad XIX. Fajar Historia: Jurnal Ilmu Sejarah dan Pendidikan, 1(2), 106-119.

Armijn Pane. 2006. Habis Gelap Terbitlah Terang, Jakarta: Balai Pustaka.

Bangun, Astri Kharina. (2021). Kisah Inspiratif 3 Kartini Modern di Bidang Bisnis dan Ekonomi. https://www.akseleran.co.id/blog/kisah-inspiratif-3-kartini-modern-dibidang-bisnis-dan-ekonomi/. Diakses tanggal 25 April 2021. 
Fatonah, Baldah. (2015). Relevansi Pemikiran R.A. Kartini Tentang Pendidikan Wanita Indonesia Dalam Kemajuan Bangsa (1891-1904). Skripsi. Universitas Pendidikan Indonesia.

Fillah, Efa. (2008). Kartini Menemukan Tuhan: Analisis Wacana Surat-surat RA. Kartini Tahun 1899-1904. Surabaya: Media Wacana Perss.

Hartutik. (2015). RA. Kartini: Emansipator Indonesia Awal Abad 20. Jurnal Seuneubok Lada, 2(1), 86-96.

Kementerian Pemberdayaan Perempuan. (2000). Rencana Induk Pembangunan Nasional Pemberdayaan Perempuan 2000-2004. Jakarta: Kantor Menteri Negara Pemberdayaan Perempuan.

Khamdiyah, H. (2016). Pemikiran Emansipasi Wanita dan Pendidikan RA. Kartini dalam Buku Habis Gelap Terbitlah Terang Karya Armijn Pane dan Relevansinya dengan Tujuan Pendidikan Islam. Skripsi. Ponorogo: STAIN Ponorogo.

Mulyani, E. (2017). Kesetaraan Gender Dalam Tulisan RA. Kartini Perspektif Pendidikan Islam. Skripsi. Porwokerto: IAIN Puirwpkerto.

Muthoifin, M., Ali, M., \& Wachidah, N. (2017). Pemikiran Raden Ajeng Kartini Tentang Pendidikan Perempuan dan Relevansinya Terhadap Pendidikan Islam. Profetika: Jurnal Studi Islam, 18(1), 36-47.

Presiden Republik Indonesia. 1964. Surat Keputusan Presiden Republik Indonesia tentang Kepahlawanan Republik Indonesia. Jakarta: Presiden Republik Indonesia.

Sasroatmojo, Suryanto. (2005). Tragedi Kartini, Yogyakarta: Penerbit Narasi.

Sudrajat. (2007). Kartini: Perjuangan Dan Pemikirannya, Mozaik: Jurnal Ilmu-ilmu Sosial dan Humaniora, 2(1), 1-14.

Suparno, Suhaenah. (2001). Wanita dan Pendidikan, Khusus di Indonesia, Yogyakarta: Sunan Kalijaga Press.

Sutrisno, Sulastin. 1979. Surat-Surat Kartini: Renungan Tentang dan Untuk Bangsanya. Jakarta: Djambatan.

Zed, Mestika. 2008. Metode Penelitian Kepustakaan. Jakarta: Yayasan Obor Indonesia. 